\title{
DUKUNGAN KELUARGA TERHADAP KELANGSUNGAN HIDUP ODHA (ORANG DENGAN HIV/AIDS)
}

\author{
Oleh Nancy Rahakbauw*
}

\begin{abstract}
HIV/ AIDS problems have not been just as problem that happens at the local level, but these become the regional and global. This issue has caused a lot of casualties, both children and adults, and even has shocked family life. HIV has affected not only medically but also has an impact psychosocial-spiritual. If this condition is not dealt with quickly and appropriately, it will be very alarming. the Indonesia people will lose generations of productive young. Therefore, in order to suppress the spread of the virus it takes the involvement and support of various parties, especially families in the treatment and care so they who infected with HIV have a longer life.

This study aimed to find out about their knowledge and understanding of people living with HIV/ AIDS (ODHA) and families on HIV disease and related issues as well as the forms of support provided by the families for ODHA in maintaining continuity their life. This study used a qualitative approach with descriptive analysis. The subject of research is HIVI AIDS infected people and their families. The study found that knowledge and understanding of ODHA and their families is very limited, this is due to lack of information obtained about HIV / AIDS and related issues. This lack has impact on the process of treatment and care done by ODHA and families. It also affects ODHA to receive treatment from their families and the surrounding environment. Whereas the family support has a very significant meaning in the process of healing people living with HIV in living of worse times when he is sentenced infected with HIV. The support could also increase the life expectancy for people living with HIV.
\end{abstract}

Keywords: HIV / AIDS, people living with HIV/ AIDS, family support

\begin{abstract}
Abstrak
Masalah HIV/AIDS bukan hanya sebagai permasalahan yang terjadi di tingkat lokal, namun sudah menjadi permasalahan regional maupun global. Masalah ini telah menimbulkan banyak korban, baik anak-anak maupun orang dewasa, bahkan telah mengguncang kehidupan keluarga. HIV bukan hanya berdampak secara medis namun juga berdampak secara psikososial-spritual. Kondisi ini sangat memprihatinkan apabila tidak ditangani dengan cepat dan tepat. Bangsa Indonesia akan kehilangan generasi muda yang produktif. Oleh karena itu, untuk menekan penyebaran virus ini maka dibutuhkan keterlibatan serta dukungan berbagai pihak terutama keluarga dalam pengobatan maupun perawatan sehingga mereka yang terinveksi HIV memiliki kehidupan yang lebih lama.

Penelitian ini dimaksudkan untuk mengetahui tentang pengetahuan dan pemahaman ODHA maupun keluarga terhadap penyakit HIV dan isu-isu yang terkait serta bentuk dukungan yang diberikan keluarga bagi ODHA dalam mempertahankan kelangsungan hidupnya. Penelitian ini menggunakan pendekatan kualitatif dan bersifat deskriptif analisis. Subyek penelitian ini adalah Orang yang terinfeksi HIV/ AIDS dan keluarga. Hasil penelitian menemukan bahwa pengetahuan dan pemahaman ODHA maupun keluarga sangat terbatas, hal ini dikarenakan kurangnya informasi yang diperoleh tentang HIV/AIDS dan isu-isu yang terkait. Ketidaktahuan ini berdampak terhadap proses pengobatan maupun perawatan yang dilakukan oleh ODHA maupun keluarga. Hal ini juga berdampak terhadap ODHA dalam menerima perlakuan dari keluarga maupun lingkungan sekitar. Padahal dukungan keluarga memiliki arti yang sangat signifikan dalam proses kesembuhan ODHA dalam menjalani masa-masa terpuruk saat divonis terinfeksi HIV. Dukungan tersebut juga meningkatkan harapan hidup bagi ODHA
\end{abstract}

Kata Kunci: HIV/AIDS, ODHA (Orang Dengan HIV/AIDS), dukungan keluarga 


\section{Pendahuluan}

Epidemi

Immunodeficiency

Immunodeficiency

HIV/AIDS

(Human

Virus/Acquired

Syndromme) semakin

berkembang cepat dan merupakan salah satu tantangan terbesar dimasa kini sekalipun telah dilakukan berbagai upaya untuk mengendalikan dan menekan penularannya. Penularan dan perkembangan kasus HIV/AIDS yang paling cepat terkonsentrasi di negara-negara dunia ketiga, dimana masyarakatnya masih bergelut dengan masalah keterbelakangan pendidikan, ekonomi, dan terutama akses terhadap pelayanan kesehatan yang belum memadai atau terjangkau. Pendidikan yang kurang dan keadaan ekonomi yang memprihatinkan menyebabkan masyarakat tidak melakukan pemeriksaan kesehatannya secara rutin sehingga mengakibatkan timbulnya berbagai penyakit, termasuk penyakit HIV/AIDS.

AIDS merupakan penyakit menular yang disebabkan karena infeksi dengan virus yang disebut HIV. Virus ini menyerang dan menghancurkan kelompok sel-sel darah putih tertentu yaitu sel T-Helper, sel yang membuat zat anti dalam tubuh. HIV memperbanyak diri dalam sel limfosit yang diinfeksikannya dan merusak selsel tersebut,sehingga mengakibatkan menurunnya sistem kekebalan dan daya tahan tubuh. Virus ini terdapat dalam darah dan air mani. Daya tahan tubuh yang melemah mengakibatkan timbulnya penyakit oleh karena infeksi ataupun penyakit lain akan meningkat.

Di Indonesia perkembangan kasus HIV/AIDS sangat pesat dan sudah menyebar ke berbagai wilayah, dari kota sampai ke desa. Virus HIV bukan hanya menyerang kaum homoseksual, pekerja seks, pengguna narkoba, tapi juga ibu-ibu rumah tangga maupun anak-anak. Temuan penting dalam dunia kedokteran untuk menekan pengembangbiakan virus HIV adalah obat Antiretroviral (ARV) yang harus dikonsumsi secara teratur. Perilakukepatuhan dalam berobat merupakan salah satu cara untuk mempertahankan agar ODHA (Orang Dengan HIV/AIDS)dapat hidup lebih lama.Kedisiplinan dalam mengkonsumsikan obat ini dapat membantu mempertahankan konsistensi efektifitas ARV dalam tubuh penderita sehingga resistensi tidak terjadi dan memperlambat berkembangnya virus dalam tubuh. ARV memang tidak bisa mematikan virus HIV di dalam tubuh, tetapi dapat menekan pengembangbiakan virus tersebut. Pada kondisi dimana ODHA seolah-olah sehat, virus tersebut juga tak terdeteksi lagi (undetectable) oleh tes
ELISA, yaitu alat yang digunakan untuk mendeteksi jumlah virus dalam tubuh.

Berdasarkan penelitian dari berbagai rumah sakit di Jakarta ditemukan bahwa obat ARV hanya mampu meningkatkan kualitas hidup ODHA sehingga terapi ARV tidak boleh dihentikan seumur hidupnya. Namun demikian tidak sedikit ODHA yang berhenti mengkonsumsi ARV setelah tubuhnya merasa lebih baik. Padahal bila ARV dihentikan, virus HIV di dalam tubuh bisa muncul lagi. Penghentian pengobatan bahkan lebih berbahaya bagi ODHA, karena berisiko membuat tubuh resisten terhadap obat tersebut. (www.pikiranrakyat.co.id).

Indikasi peningkatan ini dipicu oleh berbagai faktor, terutama kurangnya informasi dan pengetahuan publik mengenai penyakit tersebut. Hal ini menyebabkan adanya pemahaman yang salah dari masyarakat ataupun keluarga serta penderita ODHA sendiri terhadap penyakit HIV/AIDS. Berbagai reaksi yang ditimbulkan di kalangan masyarakat maupun keluarga karena ketidaktahuan tentang penyakit ini, antara lain, adalah marah, panik, terguncang, perasaan takut yang berlebihan, pengingkaran, serta pengucilan terhadap orang yang terinfeksi HIV/AIDS. Perasaan serta sikap yang reaksional terhadap penyakit HIV/AIDS menyebabkan banyak keluarga belum dan bahkan tidak siap menerima anggotanya yang terinfeksi virus tersebut. Sikap represif keluarga maupun masyarakat ini sangat mempengaruhi kehidupan bersosialisasi para ODHA dengan lingkungan sosialnya.

Permasalahan yang terkait dengan ODHA tidak sekedar masalah kesehatan saja tetapi justru masalah sosial lainnya yang menyangkut aspekaspek lain, yaitu bagaimana agar mereka hidup sehat setelah mengetahui dirinya terinfeksi virus HIV yang mematikan, serta masalah psikologis yang terutama terjadi ketika hasil tes darah ternyata positif mengidap HIV (kaget, sedih, dan stres). Masalah lain yang juga dialami oleh mereka adalah penolakan diri terhadap kenyataan bahwa ia terinfeksi virus HIV, sekalipun kelihatannya sehat. Kondisi kejiwaan inilah yang menyebabkan ODHA merasa tidak berguna, mempunyai masa depan suram, tidak dapat melakukan apa-apa untuk dirinya maupun keluarga dan tidak memiliki akses untuk memperoleh pekerjaan serta memiliki keterbatasan dalam interaksi sosialnya.

ODHA bukan hanya berurusan dengan kondisi penyakit, tetapi kondisi penyakit yang disertai dengan stigma sosial yang sangat 
diskriminatif (Brennan, 1996). Selain itu, disamping pelayanan medis yang masih sangat dibutuhkan ODHA untuk mempertahankan kesehatannya, mereka juga membutuhkan serangkaian pelayanan lain seperti dukungan psikososial dalam menghadapi situasi kehidupan yang dijalaninya sehari-hari.

Munculnya stigma atau diskriminasi masyarakat terhadap penderita HIV/AIDS terjadi karena mereka beranggapan bahwa anggotanya yang terinfeksi virus tersebut merupakan aib bagi keluarga.Stigma serta diskriminasi yang diperlihatkan oleh berbagai kalangan terhadap penderita AIDS menyebabkan ruang gerak mereka menjadi semakin kecil dan bahkan tidak diberi peluang untuk mengekspresikan diri dan kemampuannya.Diskriminasi menyebabkan mereka yang beresiko mengidap HIV/AIDS enggan atau malu melakukan pemeriksaan kesehatan, sementara mereka yang sudah positif mengidap HIV/AIDS menjadi tidak nyaman dan tidak memiliki keberanian untuk berobat. Diskriminasi dan stigmasasi akhirnya menyebabkan sulitnya kepatuhan berobat dan mengganggu perbaikan kualitas hidup ODHA.

Stigma dan diskriminasi yang dialami oleh ODHA bukanlah suatu keadaan yang statis karena merupakan sebuah proses sosial. Proses sosial terjadi dalam suatu masyarakat yang masih memengang kuat budaya dan norma agama sehingga selalu menyalahkan orang yang terinfeksi HIV/AIDS sebagai orang yang memiliki perilaku menyimpang. Pemberian label demikian menyebabkan orang dengan HIV/AIDS tidak dapat berinteraksi dengan lingkungan sosialnya secara wajar. Stigma merupakan hasil interaksi antara individu dengan lingkungan sosialnya yang dapat dipengaruhi oleh pengetahuan, sikap, kelas, jender, etnisitas, agama, dan sebagainya. Stigma dan diskriminasi sesungguhnya mencerminkan pula adanya relasi kekuasaan di dalam masyarakat (Parker dan Anggelton, 2003). Diskriminasi terhadap ODHA mempunyai hubungan erat dengan stigma terhadap HIV/AIDS, artinya stigma mendorong terjadinya diskriminasi yang pada akhirnya menyebabkan berbagai pelanggaran Hak Azasi Manusia (HAM) terhadap ODHA maupun orang yang hidup dengan HIV/AIDS (OHIDA).

Peningkatan kualitas dan harapan hidup dari penderita HIV/AIDS membutuhkan berbagai upaya dari pemerintah maupun masyarakat terutama keluarga. Pemerintah dalam hal ini Departemen Kesehatan dan instansi terkait, memiliki peranan yang sangat penting sehubungan dengan penyediaan obat-obatan maupun penyediaan layanan kesehatan ODHA. Demikian juga dalam kebijakan-kebijakan untuk mengalokasikan dana dalam menanggulagi penyebaran virus HIV serta pemberian obat secara cuma-cuma bagi penderita. Disamping itu, masyarakat sebagai unit kontrol sosial, mempunyai pengaruh besar terhadap interaksi sosial ODHA.

Peran penting selain pemerintah dan masyarakat, adalah keluarga. Keluarga merupakan unit terkecil dalam masyarakat disini didefinisikan terdiri dari ayah, ibu, anak, bibi, paman, keponakan, kakek, nenek bahkan anak angkat. Keluarga merupakan lingkungan dimana seseorang mengalami proses sosialisasi dalam pertumbuhan dan perkembangan pribadinya. Disinilah fungsi keluarga memegang kendali untuk seorang anak dalam menunjukan eksistensi dan mengaktualisasikan dirinya dalam masyarakat. "Keluarga inti merupakan pengelompokan manusia yang paling universal, terdapat disegala tempat dalam segala zaman", meskipun bentuknya mungkin sedikit berbedabeda. Tapi kita selalu melihat bahwa fungsi keluarga inti itu selalu sama, yakni hubungan seksual yang mendapat pengesahan masyarakat, fungsi ekonomi, fungsi pengembangan keturunan, dan fungsi pendidikan bagi anak-anak yang dilahirkan di dalam lingkungan keluarga tersebut. (Murdock, 1968:38).

Fungsi maupun pola kekerabatan yang selalu terbentuk dalam relasi antar anggota keluarga memiliki pengaruh yang sangat kuat bagi anggota-anggotanya, baik secara psikis maupun fisik. Polarisasi kedekatan ini terwujud dalam segala aspek kehidupan individu dalam keluarga, baik saat senang, cemas, sedih ataupun mengalami suatu peristiwa yang dapat merenggut kehidupan pribadinya. Keluargalah yang selalu ada saat seseorang membutuhkan dan memberikan perhatian serta dukungan secara material maupun non material. Pola kekeluargaan manusia sebagian ditentukan oleh tugas khusus yang dibebankan kepadanya: keluarga adalah satu-satunya lembaga sosial yang diberi tanggung jawab untuk mengubah suatu organisme biologis menjadi manusia. Pada saat sebuah lembaga mulai membentuk kepribadian seseorang dalam hal-hal penting, keluarganya tentu berperan dalam persoalan perubahan itu, dengan mengajarkan kemampuan berbicara dan menjalankan banyak fungsi sosial (Goode, 1995: 16). 
Pemahaman dan informasi terhadap penyakit AIDS yang kurang akan memberikan keleluasan bagi masyarakat dalam mengkonstruksikan dan mempertahankan pola pemikiran yang diskriminatif sehingga menciptakan pengkotakan terhadap orang dengan HIV/AIDS baik dalam dunia pendidikan, pekerjaan, kesehatan maupun dalam pergaulan lingkungan sosialnya. Situasi-situasi diciptakan sedemikian rupa sehingga menyebabkan ODHA semakin tenggelam dalam dunianya dan semakin menarik diri dari kehidupan sosialnya. Saat ODHA memasuki masa transisi sejak mengetahui dirinya terinfeksi virus HIV, disinilah keluarga menjadi penting dan menjadi satu kesatuan sistim dalam melihat dan memahami permasalahan yang sedang terjadi, karena keluarga adalah tempat seorang anak mendapatkan kasih sayang, perhatian, dan juga untuk bersosialisasi. Untuk mempertahankan pola hidup dan melanjutkan satu generasi agar tetap bertahan, maka keluarga sangat diharapkan untuk memainkan peran yang besar dalam memberi perawatan dan dukungan kepada anggota-anggotanya yang terinfeksi HIV/AIDS. Hal ini sangat penting karena dukungan yang diberikan oleh keluarga merupakan suatu mata rantai dalam proses kesembuhan dan proses persiapan ODHA agar dapat kembali bersosialisasi dengan lingkungannya dan menjalani hidup yang wajar.

\section{Tinjauan Teoritis}

\subsection{Pengertian HIV/AIDS}

a. Pengertian ODHA (Orang Dengan HIV/AIDS)

ODHA adalah singkatan dari Orang Dengan HIV/AIDS, sebagai pengganti istilah penderita yang mengarah pada pengertian bahwa orang tersebut secara positif didiagnosa terinfeksi HIV. HIV adalah virus penyebab AIDS yang menyerang sistem kekebalan tubuh (Diane, 2002:1). Fungsi dari sistem kekebalan tubuh itu sendiri sangat vital karena melindungi terhadap segala penyakit. Bila sistem kekebalan tubuh tidak berfungsi dengan baik atau dirusak oleh virus maka akan berakibat kematian.Secara terusmenerus HIV memperlemah sistem kekebalan tubuh dengan cara menyerang dan menghancurkan kelompok sel-sel darah putih tertentu yaitu sel T- helper, sel yang membuat zat anti dalam tubuh.

HIV adalah sejenis parasit yang hanya dapat hidup dalam sel tubuh manusia. Ukuran virus HIV kecil sekali, untuk dapat menutupi satu titik (.) saja, dibutuhkan sekitar 500.000.000 lebih virus HIV. Hal yang perlu diperhatikan adalah bahwa tidak semua orang yang menderita infeksi HIV akan langsung menunjukan gejala klinis, dan ini menyebabkan orang dengan HIV/AIDS (ODHA) bahkan orang-orang yang berada didekat mereka tidak mengetahui bahwa ia sudah terinfeksi virus tersebut.

Pembagian tingkat klinis penyakit virus HIV oleh Global Programme on AIDS dari Badan Kesehatan Dunia (WHO) mengusulkan "pembagian tingkat klinis penyakit HIV" pada pertemuan di Jenewa bulan Juni 1989 dan Februari 1990, berdasarkan penelitian terhadap 907 penderita zeropositif HIV dari 26 Pusat Perawatan yang berasal dari 5 benua. Pembagian tingkat klinis HIV tersebut adalah sebagai berikut:

1) Tingkat Klinis 1 (Asiptomatik/LGP): tanpa gejala sama sekali atau mengalami Linfadenopati Generalisata Persisten (LPG), yakni pembesaran kelenjar getah bening di beberapa tempat yang menetap.Pada tingkat ini, pasien belum mempunyai keluhan dan tetap dapat melakukan aktivitas.

2) Tingkat Klinis 2 (dini): penurunan berat badan kurang dari $10 \%$; kelainan kulit dan mulut yang ringan, misalnya dermatitis seboroika, prurigo, infeksi jamur pada kaki, ulkas pada mulut berulang, dan chelitis anguralis;herpes zoster yang timbul pada lima tahun terakhir; dan infeksi saluran nafas bagian atas berulang, misalnya sinusitis.Pada tingkat ini, pasien sudah menunjukkan gejala tetapi aktivitasnya tetap normal

3) Tingkat Klinis 3 (menengah): penurunan berat badan lebih dari $10 \%$, diare kronik lebih dari 1 bulan, dengan penyebab tidak diketahui; panas yang tidak diketahui sebabnya selama lebih dari 1 bulan, hilang-timbul, maupun terus menerus; kandidiasis mulut, bercak putih berambut di mulut; tuberkolosis setahun terakhir; infeksi bakteriil yang berat, misalnya pnemonia. Pada tingkat ini, penderita biasanya berbaring di tempat tidur lebih dari 12 jam per hari.

4) Tingkat Klinis 4 (lanjut): badan menjadi kurus (HIV Wasting Sydrome), yaitu berat badan turun lebih dari $10 \%$ dan diare kronik lebih dari sebulan dengan penyebab tidak diketahui, atau kelemahan kronik timbul panas yang tidak diketahui sebabnya selama lebih dari 1 bulan: pnemonia pneumosistis karini, toksoplasmosis otak; kriptosporidiosis dengan diare lebih dari 1 bulan, penyakit virus sitomegalo pada organ tubuh, kecuali di limfa, hati, atau kelenjar getah 
bening; infeksi virus herpes simpleks dimukokutan lebih dari satu bulan, atau di alat dalam (visceral) lamanya tidak dibatasi; mikosis (infeksi jamur) apa saja, tuberkulosis di luar paru; limfoma, sarcoma Kaposi; ensefatopati HIV, sesuai kriteria Center for Disease Control and Prevention (CDC) yaitu gangguan kognitif atau disfungsi motorik yang mengganggu aktivitas sehari-hari, progresif setelah beberapa minggu atau beberapa bulan, tanpa ditemukan penyebab selain HIV.

\section{(Rustamaji, 2000:134-135)}

Pengidap HIV bila tidak ditangani sedini mungkin secara tepat dan cepat berakibat sangat fatal, dan berdasarkan hasil penelitian, HIV merupakan virus penyebab AIDS (Richard D. Munna, dkk. 1997: 23). Namun demikian, tidak semua pengidap virus HIV akhirnya menderita AIDS. Berdasarkan studi yang pertama menunjukkan sekitar 1 dari 10 orang yang tertular virus ini akan berakhir dengan menderita AIDS karena masa antara infeksi dengan munculnya gejala memakan waktu beberapa tahun (Diane Richardson, 2002:5). Diperkirakan waktu antara terinfeksi HIV dan terbentuk AIDS bervariasi antara 1-10 tahun, dengan perkiraan rata-rata waktu 7-8 tahun (Kaplan,1993).Orang dengan HIV positif sangat rentan terhadap serangan virus sehingga kondisi tubuh dapat melemah secara cepat dan berkembang menjadi AIDS(Acquired Immune Deficiency Syndrome). (Kaplan,1993;Taylor; Sarafino,2002).

Penyakit AIDS jika diterjemahkan secara bebas adalah sekumpulan gejala penyakit yang menunjukan kelemahan atau kerusakan daya tahan tubuh yang didapat dari faktor luar (bukan bawaan sejak lahir). Jadi AIDS merupakan sekumpulan gejala-gejala penyakit infeksi atau keganasan tertentu yang timbul sebagai akibat menurunnya daya tahan tubuh (kekebalan) penderita (Trijatno Rachimhadhi, 1996 : 1).

Penderita AIDS menjadi peka terhadap infeksi termasuk kuman yang dalam keadaan normal sebenarnya tidak berbahaya, dan hal ini disebabkan tubuhnya telah mengalami kerusakan sistim kekebalan tubuh. Infeksi kuman bentuk ini disebut sebagai infeksi oportunistik.

\section{b. Gejala-gejala HIV/AIDS}

Gejala penyakit pada penderita HIV mirip dengan penyakit biasa seperti demam, bronchitis dan flu, akan tetapi pada penderita AIDS, gejala- gejala ini biasanya lebih parah dan berlangsung dalam waktu yang lebih lama. Seperti yang dikemukakan oleh Diane Richardson (2002:25) gejala umum HIV/AIDS mencakup hal-hal sebagai berikut:

1) Kelelahan yang sangat, yang berlangsung selama beberapa minggu tanpa sebab yang jelas

2) Demam tanpa sebab yang jelas, menggigil kedinginan atau berkeringat berlebihan di malam hari, berlangsung selama beberapa minggu.

3) Hilangnya berat badan lebih dari $5 \mathrm{~kg}$ dalam waktu kurang dari dua bulan.

4) Pembengkakan kelenjar, terutama di leher atau ketiak.

5) Sariawan sejenis bisul atau luka bernanah di mulut atau tenggorokan. Sariawan adalah infeksi yang umumnya terjadi di vagina, mengakibatkan keluarnya cairan putih yang menggangu (jamur vagina tidak berhubungan dengan AIDS). Pada laki-laki jamur ini timbul berupa bintik-bintik putih yang menggangu ujung penis atau munculnya kotoran putih yang keluar dari anus.

6) Diare terus menerus.

7) Nafas menjadi tidak stabil, lambat-laun menjadi buruk setelah beberapa minggu, disertai dengan gangguan batuk kering yang tidak diakibatkan oleh rokok dan berlangsung lebih daripada batuk karena flu.

8) Bisul jerawat baru, berwarna merah muda atau ungu rata atau timbul (biasanya tidak sakit) muncul dikulit bagian mana saja, termasuk dimulut atau kelompak mata. Dalam banyak kasus luka-luka tersebut dapat juga timbul organ bagian dalam seperti misalnya selaput paru-paru, usus atau anus. Awalnya luka tersebut melepuh, berdarah atau memar, tetapi tidak memucat jika ditekan dan tidak hilang. Biasanya luka melepuh ini salah satu bentuk kanker kulit yang dikenal dengan leaposis sarcoma.

\section{c. Dampak Virus HIV/AIDS}

Virus HIV/AIDS menimbulkan dampak yang sangat luas dan serius bagi si penderita, masyarakat dan keselamatan bangsa, baik psikis, fisik maupun sosial. Kondisi ini seringkali mempengaruhi proses kesembuhan yang harus dilakukan oleh ODHA.Tekanan-tekanan psikologis yang dialami oleh ODHA merupakan faktor utama penyebab kondisi menjadi lemah kembali. Seperti yang dikemukakan oleh Richard D. Muma dan kawan-kawan (1997: 279) yang 
mengatakan bahwa dampak yang dialami oleh penderita HIV adalah:

1) Kecemasan: rasa tidak pasti tentang penyakit yang diderita, perkembangan dan pengobatannya, merasa cemas dengan gejalagejala baru, prognosis, dan ancaman kematian, hiperventilasi, serangan panik.

2) Depresi: merasa sedih, tidak berdaya, rendah diri, merasa bersalah, tidak berharga, putus asa, berkeinginan untuk bunuh diri, menarik diri, memberikan ekspresi pasrah, sulit tidur, dan hilang nafsu makan.

3) Merasa terisolasi dan berkurangnya dukungan sosial, merasa ditolak oleh keluarga, dan orang lain. Sedikitnya orang yang menjenguk pada saat ODHA dirawat semakin memperkuat perasaan ini.

4) Merasa takut bila ada orang yang mengetahui atau akan mengetahui penyakit yang dideritannya.

5) Merasa khawatir dengan biaya perawatan, khawatir kehilangan pekerjaan, pengaturan hidup selanjutnya dan transportasi.

6) Merasa malu dengan adanya stigma sebagai penderita AIDS, penyangkalan terhadap kebiasaan seksual.

7) Penyangkalan hidup riwayat penggunaan obatobatan terlarang.

\subsection{Pengobatan Terhadap HIV/AIDS}

Menurut Sarafino (2002), sebagian ODHA yang mengalami lemahnya sistim kekebalan tubuh dan opportunistic infection, dapat ditangani efektif secara medis. Tetapi kadangkala orang yang terkena HIV/AIDS menjadi hipersensitif atau alergi terhadap pengobatan, dan hingga saat ini tidak ada terapi yang memungkinkan tubuhnya akan mampu mentolerir virus tersebut. Jika tidak ditangani, opportunistic infection ini dapat menyebabkan kematian kira-kira 3 tahun setelah didiagnosa mengalami AIDS.

Menurut Gavze (dalam Sarafino, 2002) ada sebagian kecil pasien yang dapat bertahan lebih dari 3 tahun, dapat hidup dan tetap aktif setelah beberapa tahun didiagnosis, karena adanya perbedaan biologis dan psikososial dari masingmasing pasien. Hal ini diperkuat oleh pendapat Cole \& Kemeny (dalam Sarafino, 2002), bahwa orang dengan HIV sangat reaktif terhadap stres dan tidak dapat melakukan coping dengan benar, memperlihatkan fungsi kekebalan tubuh yang sangat rendah dan progresivitas penyakit yang sangat cepat, dibandingkan dengan yang lain.
Penanganan AIDS melalui pengobatan yang disebut sebagai antiretroviral agent. Pertengahan tahun 1980-an, obat utama bagi AIDS adalah AZT (azidothymidine) yang berfungsi untuk memperlambat reproduksi HIV pada tahapan awal. Selanjutnya di pertengahan tahun 1990-an berkembang obat anti-retroviral baru yang disebut sebagai protease inhibitor, yang juga berfungsi untuk menangani reproduksi HIV dan secara dramatis mengurangi jumlah virus tersebut dalam banyak infeksi HIV yang dialami, tetapi tidak semuanya. (Sarafino, 2002; Alloy,2005).

Antiretroviral (ARV) adalah suatu obat yang dapat digunakan untuk mencegah reproduksi retrovirus yaitu virus yang terdapat pada HIV. Obat ini tidak untuk mencegah penyebaran HIV dari orang yang terinfeksi ke orang lain, tidak untuk menyembuhkan infeksi HIV dan juga tidak berfungsi untuk membunuh virus. Antiretroviral digunakan untuk memblokir atau menghambat proses reproduksi virus, membantu mempertahankan jumlah minimal virus di dalam tubuh dan memperlambat kerusakan sistem kekebalan sehingga orang yang terinfeksi HIV dapat merasa lebih baik/nyaman dan bisa menjalani hidup normal. (www.chclibrary.org)

Berdasarkan uraian diatas dapat disimpulkan bahwa penyakit HIV/AIDS merupakan suatu penyakit yang dapat menyerang sistim kekebalan tubuh manusia dan tidak memberikan peluang bagi orang yang terinfeksi untuk terbebas dari serangan virus yang mematikan. Kondisi ini mengakibatkan munculnya gejala-gejala dan juga dampak yang sangat besar terhadap kehidupan sosial maupun harapan untuk tetap hidup. Untuk dapat menjalankan hidup dan tetap produktif dalam melakukan berbagai aktivitas sebagaimana mestinya, maka ODHA harus mengkonsumsikan obat ARV karena obat tersebut dapat memperlambat berkembangnya virus HIV selain itu juga perlu menjaga pola hidup yang sehat, karena ini merupakan suatu bentuk rangkaian situasi kesehatan yang harus tetap diprioritaskan.

Kedisiplinan dan kepatuhan dalam mengkonsumsi obat maupun pola hidup yang sehat akan memberikan dampak yang positif terhadap kondisi fisik maupun psikis, karena keseimbangan antara kedua faktor tersebut dapat menstimulus pemahaman dan pemikiran yang bermakna terhadap masa depan maupun sikap optimisme dalam menjalankan dan melakukan interaksi kehidupan sosial sehari-hari. 
Faktor psikis dan fisik memiliki hubungan yang sangat erat. Kehidupan fisik yang stabil sangat mempengaruhi kestabilan jiwa dan jika fisik dalam kondisi sakit maka akan mempengaruhi kejiwaan seseorang.Pardeck et.al. (1998: 29) menyatakan, "Health is a state of holistic well-being. It means being connected in a fulfilling way with the natural and human world."(Sehat adalah suatu keadaan sejahtera secara menyeluruh. Ini berarti terkait dengan cara pemenuhan kehidupan dengan dunia yang alami dan manusiawi)

Dalam Jurnal Psikologi Kesehatan, Mustafid Amna (2003) mengatakan, kesehatan seseorang tak hanya diukur dari kebugaran fisik, tetapi juga dari kewarasan psikis, serta kelancaran interaksi sosial. Bukan hanya itu, WHO (1984) telah menyempurnakan batasan sehat dengan menambahkan elemen spiritual. Dengan demikian, sekarang ini yang dimaksud sehat bukanlah hanya sehat dalam arti fisik, psikologik, dan sosial, tetapi juga sehat dalam arti spiritual. Dengan kata lain, merujuk kepada WHO, terdapat empat dimensi sehat, yakni bio-psiko-sosialspiritual.

Masalah kesehatan, merupakan masalah utama yang harus menjadi perhatian serius dalam setiap kehidupan manusia. Artinya seseorang akan menentukan aktivitas kehidupan sehari-hari tergantung dari kesehatannya.Kesehatan seseorang tidak bisa hanya dilihat dari kondisi fisik saja, tetapi harus dilihat secara holistik. Seseorang yang dikatakan sehat adalah mampu melakukan segala aktivitas kesehariannya dan dapat berperan secara maksimal dalam kehidupan sehari-hari, baik sebagai pribadi maupun sebagai anggota masyarakat. Manusia sehat adalah manusiamanusia yang mampu memanfaatkan potensipotensi yang ada pada dirinya untuk mencapai tujuan hidup

\subsection{Pelayanan Kesehatan}

Pelayanan kesehatan adalah pelayanan yang sangat dasar, dan diperlukan oleh semua orang, sejak bayi sampai pada kasus kesakitan yang permanen (Joseph and Phillips, 1984). Pada tahun 1971 Konferensi Internasional mengenai Pelayanan Kesehatan Dasar yang diadakan di Alma-Ata, USSR, mendeklarasikan bahwa pelayanan kesehatan dasar adalah kunci untuk mencapai "health for all", atau merupakan pelayanan yang esensial. Deklarasi ini kemudian disebut dengan Deklarasi Alma-Ata (WHO, 1981). Konferensi ini mengkonfirmasikan ulang bahwa kesehatan adalah kesehatan secara mental, fisik, sosial, bukan hanya sekedar tidak sakit. Kesehatan adalah hak azasi manusia dan pencapaian kesehatan yang maksimal adalah hal yang sangat penting terhadap kegiatan sosial serta perekonomian.

Pelayanan kesehatan yang disediakan oleh pemerintah dengan fasilitas yang modern serta biaya yang terjangkau diperuntukkan dan diprioritaskan bagi masyarakat yang membutuhkan untuk mengakses layanan yang ada dengan semaksimal mungkin sehingga dapat meningkatkan kualitan hidup sehat dan mengarah kepada kemajuan dan kesehatan secara menyeluruh. Hal ini terimplementasi melalui sistim rujukan yang terintegrasi, berfungsi secara maksimal serta bermutu. (WHO,1981).

Kesehatan seseorang sangat dipengaruhi oleh cara berpikir terhadap pola hidup yang dijalaninya. Kondisi kesehatan ODHA sangat tergantung pada diri sendiri dan juga dipengaruhi oleh orang yang berada disekitar kehidupannya, dalam hal ini keluarga, teman dan juga tetangga. Interaksi antara ODHA dengan lingkungan sosial memberikan dampak yang besar terhadap kondisi kesehatan secara menyeluruh baik itu kesehatan fisik, mental, sosial maupun spiritual. Dengan kedekatan maupun interrelasi yang terjadi dengan orang-orang yang berada disekitar ODHA dapat membantu untuk melihat kehidupan yang lebih bermakna dan berharga bagi dirinya maupun orang lain.

Keyakinan dan dorongan yang dimiliki karena merasa dibutuhkan dan menjadi bagian dari lingkungan, memotivasi dan mendorong ODHA dalam menjaga maupun merawat dirinya dengan melaksanakan pola hidup yang teratur dan disiplin serta berpikir positif untuk mempertahankan harapan hidup, serta dapat produktif dalam melakukan aktivitas apapun.

Health belief model adalah teori yang diuraikan dalam usaha mencari cara menerangkan perilaku yang berkaitan dengan kesehatan. Menurut teori ini, kemungkinan individu akan melakukan tindakan pencegahan tergantung secara langsung pada hasil dari dua keyakinan atau penilaian kesehatan yaitu ancaman yang dirasakan serta sakit atau luka dan pertimbangan tentang keuntungan dan kerugian (Smet,1994). Penilaian pertama adalah ancaman yang dirasakan terhadap resiko yang muncul. Hal ini mengacu pada sejauh mana seseorang berpikir penyakit atau kesakitan betul-betul merupakan ancaman kepada dirinya. Asumsinya adalah bahwa bila ancaman yang 
dirasakan tersebut meningkat maka perilaku pencegahan juga akan meningkat. Keyakinan seseorang terhadap kesehatan dialaminya sangat mempengaruhi cara berfikirnya dalam melihat kehidupan dan bagaimana menjalani hidup untuk lebih berarti bagi dirinya maupun orang lain. Hal ini terkait dengan bagaimana ODHA memaknai kehidupannya dan meningkatkan kualitas hidup dengan berfikir positif dalam menjalani hidup sehari-sehari.

\subsection{Makna Hidup}

Dalam kehidupannya manusia seringkali tidak dapat menghindari peristiwa-peristiwa tragis yang menimpa dirinya, keluarga, dan lingkungan, sekalipun usaha pencegahan dan upaya penanggulangannyapun telah dilakukan secara optimal. Peristiwa-peristiwa yang membuat seseorang menjadi kehilangan untuk mencapai tujuan hidup adalah mengalami penyakit yang tidak dapat disembuhkan seperti HIV/AIDS ataupun kehilangan orang-orang yang dicintai serta musibah-musibah lainnya. Peristiwaperistiwa itu, baik yang bersumber dari dalam maupun dari lingkungan akan mengakibatkan stres, perasaan kecewa, tertekan, sedih, cemas, rendah diri, dan tidak bermakna. Bahkan mungkin saja hal ini menimbulkan sejumlah gangguan penyakit, dan kejiwaan serta berbagai perilaku yang menyimpang. Di lain pihak, ada juga pribadi yang berhasil dengan gemilang mengatasi kesulitan-kesulitan dan perasaan-perasaan tidak menyenangkan akibat penderitaan.

Individu mampu mengubah dirinya dari penghayatan tidak bermakna (meaningless) menjadi bermakna (meaningfull), bahkan tidak sedikit yang berhasil menemukan hikmah dari penderitaannya (meaning in suffering). Upayaupaya pribadi yang mengatasi penderitaan adalah cara dalam menemukan makna hidup (the meaning of life) serta mengembangkan hidup secara bermakna (the meaningfull life). (Bastaman:1993)

Makna hidup memberikan arti yang khusus bagi seseorang dan jika berhasil dipenuhi akan dirasakan dalam menjalankan kehidupan kebahagiaan yang penuh arti dan berharga (Frankl,1993:20). Hal senada juga dikatakan oleh H.D Bastaman (1996:132) yakni makna hidup memiliki fungsi sebagai tujuan hidup yang sangat penting bagi kehidupan pribadi seseorang serta mempunyai nilai-nilai khusus yang dapat diarahkan melalui kegiatan-kegiatan yang dilakukannya.
Selanjutnya makna hidup menurut Ancok (2001), adalah sebuah motivasi yang kuat dan mendorong untuk melakukan sesuatu kegiatan yang berguna. Hidup yang berguna adalah hidup yang terus memberi makna pada diri sendiri dan orang lain. Berkaitan dengan makna hidup Langgulung (2003:17), mengatakan bahwa manusia dalam hidupnya terdorong oleh keinginan yang kuat untuk mencapai makna bagi hidupnya serta terdorong mengungkapkan dan mengaktualkan diri secara bebas untuk mewujudkan potensi-potensi yang dimiliki sesuai dengan cara yang diinginkannya.

Crumbaugh dan Maholick (1992:147), menggabungkan makna dan maksud hidup (purpose in life) sebagai "Signifikansi ontologism hidup" dari sudut pandang individu yang mengalaminya. Yang dimaksud dengan signifikansi ontologisme adalah pengalamanpengalaman hidup individu yang terkait dengan makna hidup, kepuasan hidup, kebebasan, sikap terhadap kematian, pikiran tentang bunuh diri dan kelayakan hidup.

Dalam proses sosialisasi diketahui bahwa tidak setiap individu memperoleh kesempatan yang sama untuk dapat mengembangkan seluruh potensinya seoptimal mungkin. Diketahui pula bahwa masing-masing individu mengalami perkembangan pribadi yang berbeda dan bahkan bersifat unik. Pada saat seseorang mengalami hambatan internal maupun eksternal. Ada yang gagal mengatasinya karena mekanisme penyesuain diri atau mekanisme penyelesaian masalah yang dikembangkan sampai saat itu tidak cukup berfungsi. Ketidakmampuan mengatasi kesulitan hidupnya merupakan hasil interaksinya dengan individu lainnya beserta lingkungannya, yang mungkin tidak berkembang secara sempurna atau tidak efektif. Keberfungsian-sosial yang terganggu pada seorang individu akan mempengaruhi interaksinya dengan individu lain. Jika hal ini terjadi dalam keluarga, individu yang mengalami gangguan keberfungsian sosial tersebut sebagai orang yang teridentifikasi mengalami masalah (Satir: 1954). Oleh karena itu ada pihak lain yang melakukan intervensi terhadap keluarga tersebut supaya keberfungsian sosial keluarga dan orang yang teridentifikasi bermasalah (the identified patient) dapat dipulihkan, dan bahkan ditingkatkan kemampuannya. Salah satu profesi yang memberikan pelayanan dan pertolongan kepada individu adalah Pekerjaan Sosial. 


\subsection{Stigma dan Diskriminasi}

Stigma diartikan sebagai pemberian cap (label) kepada seseorang atau sekelompok orang yang didasarkan pada penilaian subjektif. Sedangkan diskriminasi adalah tindakan pengucilan terhadap seseorang atau sekelompok orang. Stigma menghadirkan suatu penilaian yang dapat menghambat proses perubahan seorang ODHA dalam memaknai hidupnya dan berfikir secara positif sebagai bagian dari warga masyarakat. Stigma yang telah dibangun di tengah masyarakat yang memiliki pemahaman yang salah terhadap ODHA maupun penyakitnya. Hal ini menimbulkan berbagai prasangka dan ketakutan yang berlebihan dari masyarakat dengan memandang penyakit AIDS diakibatkan karena perilaku seks yang menyimpang, pecandu narkotik suntik, dan ODHA lelaki disamakan dengan kaum homoseksual. Ketakutan dan kecemasan yang terjadi menyebabkan berbagai bentuk penolakan dan pengucilan dari seluruh aspek kehidupan manusia.Berbagai bentuk penolakan dan pengucilan yang diskriminatif menyebabkan ODHA tidak dapat menjalankan tugasnya dan tanggungjawab sosial sebagai warga masyarakat. Perlakuan masyarakat dengan memberikan stigma maupun diskriminasi dipengaruhi oleh beberapa faktor (Dit. RTS 2004), yaitu:

a. Ketidaktahuan tentang informasi yang benar dan baik tentang HIV/AID

b. Berkembangnya mitos-mitos HIV di masyarkat

c. Adanya ketakutan yang irasional akan tertular HIV/AIDS

d. HIV sering dikaitkan dengan isu-isu moral

Stigma (cap buruk) dan diskriminasi (perlakuan tidak adil) yang dikaitkan dengan HIV dan AIDS merupakan penghambat utama bagi upaya lanjut dalam pencegahan infeksi dan pelayanan yang memadai, dukungan dan perawatan serta pengurangan dampak buruk infeksi HIV. Keadaan ini memberi konsekuensi psikologis yang besar bagi ODHA untuk dapat melihat diri mereka sendiri, yang kemudian akan membawa mereka dalam beberapa kasus pada keadaan depresi, kurang percaya diri dan putus asa. Stigma dan diskriminasi yang terkait dengan HIV/AIDS akan mempengaruhi kapasitas masyarakat dalam merespon keadaan ini secara konstruktif guna menghadapi kerugian yang diakibatkan oleh epidemi ini. Dalam bencana dan ketidakinginan membicarakan epidemi ini, kegiatan akan berkurang karena adanya stigma dan penyangkalan, dan terutama karena orang menjadi takut untuk membuka diri.
Stigma seputar HIV/AIDS muncul dalam berbagai konteks, termasuk dalam ruang lingkup keluarga, komunitas, pendidikan, pekerjaan, rumah sakit, klinik, yang semuanya membawa dampak terhadap berbagai akses dan kesempatan untuk memperoleh pelayanan. Bila stigma tidak dilawan, maka akan menimbulkan terbentuknya kesadaran diri (bagaimana orang memandang dirinya), dan yang lebih membahayakan adalah timbulnya suatu keyakinan terhadap diri sendiri bahwa cap buruk yang diberikan adalah sudah sewajarnya diterima sebagai suatu kenyataan. Hal ini mengakibatkan orang menjadi malu, merasa rendah diri dan merasa tidak berharga. Akibat yang dialami memberikan dampak kepada ODHA menjadi pribadi yang tertutup, menarik diri dari pergaulan sosialnya, eksklusif, dan bahkan tidak percaya lagi kepada orang diluar kelompoknya.

Menurut Bruyn 1998(dalam Dit RTS 2004),stigma adalah "Ekspresi dari norma sosial dan budaya, yang membentuk hubungan antar manusia menurut norma-norma tersebut. Orangorang yang distigma biasanya dianggap memalukan untuk alasan-alasan tertentu, dan sebagai akibatnya mereka dipermalukan, dihindari, dideskriditkan, ditolak, ditahan atau dihukum".

Deklarasi Komitmen Perserikatan BangsaBangsa tentang Penanggulangan HIV/AIDS (2001) menyatakan:

a. Adanya stigma, kebisuan, perlakuan tidak adil dan penyangkalan serta tidak terjamin kerahasian, menghambat upaya pencegahan, perawatan dan pengobatan sehingga meningkatkan dampak epidemi bagi bagi individu, keluarga masyarakat, dan bangsa' (Butir. 13)

b. Menjelang tahun 2003, nnegara-negara harus memastikan perkembangan dan pelaksanaan strategi nasional dari rencana keuangan nasional multi-sektor untuk memerangi HIV/AIDS yang membahas epidemi secara terbuka; menghadapi stigma, kebisuan dan penyangkalan, membahas dimensi epidemi yang berkaitan dengan usia dan jender, serta memberantas diskriminasi dan penyingkiran' (Butir. 37).

c. Menjelang tahun 2003, negara-negara harus mengesahkan, mendukung atau menegakkan peraturan serta kebijakan lain untuk menghilangkan segala bentuk diskriminasi dan menentukan nikmatnya semua hak azasi manusia serta kemerdekaan hakiki oleh, orang yang hidup dengan HIV/AIDS, dan juga orang- 
orang yang berisiko tinggi, agar mereka bisa mendapatkan akses terhadap pendidikan, warisan, pekerjaan, pelayanan kesehatan, layanan masyarakat, pencegahan, informasi dan perlindungan hukum, sementara di sisi lain tetap menghormati hak pribadi mereka, dan mengembangkan strategi untuk melawan stigma dan pengucilan sosial yang terkait dengan epidemi ini. (Butir. 58)

Hal ini dapat diartikan bahwa dengan
adanya peryataan sikap bersama dalam
memberantas atau melakukan pencegahan
HIV/AIDS oleh negara-negara di dunia yang
penduduknya beresiko terinfeksi virus HIV
dalam membuat dan menciptakan suatu kebijakan
serta peraturan yang mendukung keberadaan
ODHA di segala aspek kehidupan tanpa mendapatkan perlakuan yang diskriminatif.

Stigma sangat berbahaya, karena bisa menimbulkan rasa malu, bersalah, dan pengucilan terhadap ODHA, dan juga karena pikiran-pikiran negatif dapat menyebabkan orang terpaksa melakukan hal-hal yang merugikan orang lain, misalnya tidak memberikan layanan atau memenuhi hak mereka. Stigma terhadap HIV/AIDS dapat mengakibatkan diskriminasi terkait HIV/AIDS. Dan ini bisa menjurus kepada pelanggaran terhadap hak azasi orang dengan HIV/AIDS, kepada keluarga mereka atau bahkan orang-orang yang dianggap terinfeksi, seperti anggota keluarga dan kerabatnya.

Diskriminasi menurut UNAIDS (1998), adalah : Sebagai "tindakan yang disebabkan perbedaan yang menghakimi terhadap orangorang berdasarkan status HIV mereka, baik yang pasti maupun yang diperkirakan, atau keadaan kesehatan mereka".(Dit RTS,2004). Sangat penting untuk mengetahui kaitan antara stigma, diskriminasi, dan pelanggaran hak azasi manusia, yaitu:

a. Stigma,diskriminasi, dan pelanggaran HAM saling terkait. Semua ini membentuk, menguatkan, dan mensahkan satu sama lain. Mereka membentuk semacam lingkaran setan.

b. Pembebasan dari diskriminasi adalah hak azasi manusia, dimana harus ada kerangka acuan untuk tindakan yang bertanggung jawab dan bisa dipertanggungjawabkan guna menghadapi masalah ini. (Yayasan Spritia, 2003)

\subsection{Keluarga dan Fungsinya}

Keluarga merupakan lingkungan sosial terdekat, dan sangat signifikan berpengaruh terhadap perkembangan dan kehidupan secara umum. Keluarga didifenisikan sebagai unit terkecil, dimana unit sosial tersebut terdiri dari unsur "orang tua" dan "anak".

Menurut Lemme (1995) keluarga adalah suatu sistem sosial independen, di mana di dalamnya terdapat hubungan yang saling mempengaruhi dan timbal balik antara anggota dalam sistem tersebut. Penjelasan yang diungkapkan Lemme tersebut memberikan pengertian keluarga yang lebih luas dari sekedar unit sosial yang beranggotakan "orang tua" dan "anak" saja. Dalam pengertian ini, suatu sistim yang terdiri dari orang tua, anak, kakek, nenek, paman, bibi atau individu lain yang memiliki interaksi dan hubungan interdependen dapat dipandang sebagai suatu keluarga. Keluarga adalah unit dalam masyarakat yang bertanggungjawab untuk menjamin terpenuhinya kebutuhan dasar anak. Cara terbaik membantu anak adalah dengan mendukung kapasitas keluarganya untuk merawat anakanak.Mempertahankan keluarga akan meningkatkan keterikatan antara orangtua dan anak serta adik-kakak.

Keluarga mempunyai sistim jaringan interaksi yang lebih bersifat hubungan interpersonal, dimana masing-masing anggota dimungkinkan mempunyai intensitas hubungan satu sama lain, antara ayah dengan ibu, ayah dengan anak, ibu dengan anak, maupun antara anak dan anak. Keluarga merupakan lembaga dasar dalam masyarakat dan disebut juga sebagai masyarakat terkecil.Keluarga juga menjadi lingkungan pertama yang dijumpai oleh seorang anak ketika dilahirkan di dunia.

Keluarga memiliki ciri-ciri secara umum dan khusus. Ciri-ciri keluarga secara umum adalah: keluarga merupakan hubungan perkawinan; berbentuk perkawinan atau susunan kelembagaan yang sengajadibentuk dan dipelihara; merupakan tempat tinggal bersama, rumah atau rumah tangga yang walau bagaimanapun tidak mungkin terpisah dari kelompok keluarga.Adapun cirri-ciri khusus keluarga adalah: kebersamaan; mempunyai dasar emosional; ada pengaruh perkembangan; posisi inti dalam struktur sosial; tanggung jawab para anggota; aturan masyarakat; serta sifat kekekalan dan kesementaraannya. (McIver Pagedalam Khairuddin, 1985)

Secara singkat dapat dikatakan bahwa keluarga merupakan tempat dan berfungsi untuk memenuhi pelbagai kebutuhan manusia mulai dari 
kebutuhan primer ( sandang, pangan, papan), kebutuhan rasa aman, kebutuhan untuk mencintai dan dicintai, kebutuhan harga diri, sampai dengan kebutuhan aktualisasi diri ( Abraham H, Maslow dalam Frank G. Goble, 1994, hal. 41).

Setiap keluarga mempunyai kedudukan utama, yaitu:

a. Berfungsi sebagai pengantara dengan masyarakat luas

b. Berfungsi sebagai pemenuhan kebutuhan yang beragam agar dapat bertahan. Perlu adanya sikap memovitasi pribadi-pribadi untuk mengabdikan kepentingan umum sehingga masyarakat dapat bertahan dan juga sebagai kontrol sosial.

c. Berfungsi sebagai jaringan sosial yang besar

d. Berfungsi sebagai pendukung masyarakat agar dapat bertahan demikian juga sebaliknya keluarga dapat bertahan karena dukungan masyarakat. ( William J. Goode, 1993: 3-4 )

Subandiroso (1987:21) mengklasifikasikan fungsi keluarga sebagai berikut: melindungi setiap anggota keluarga; memberi pendidikan kepada anak; melakukan kegiatan ekonomi; dan mengasuh serta membesarkan anak. Adapun Yadi Mulyadi dkk (1995:108) mengemukakan fungsi keluarga sebagai berikut: melakukan keturunan atau reproduksi; afeksi atau kasih sayang; sosialisasi; ekonomi; pengawasan / kontrol sosial; dan proteksi atau perlindungan. Selanjutnya menurut McIver Page (dalam Khairuddin,1985: 9)fungsi keluarga adalah merawat, memelihara, melindungi anak dalam rangka sosialisasinya agar mereka mampu mengendalikan diri dan berjiwa sosial.

Berdasarkan fungsi keluarga yang disampaikan oleh para pakar di atas dapat disimpulkan bahwa fungsi keluarga adalah sebagai pemenuhan semua aspek kehidupan secara menyeluruh untuk pertumbuhan dan perkembangan dalam mengaktualisasikan diri dan melakukan interaksi terhadap lingkungan yang lebih besar yaitu masyarakat. Pada setiap keluarga terdapat berbagai macam fungsi antara lain: fungsi reproduksi, fungsi sosialisasi, fungsi ekonomi, fungsi afeksi, fungsi perlindungan atau keamanan, fungsi penentuan status, dan fungsi edukatif.

\subsection{Dukungan Sosial}

Manusia sebagai makhluk sosial selalu berinteraksi dengan lingkungan sosialnya, yang selalu memberikan pengaruh dalam perkembangan kepribadian individu sebagai makhluk sosial. Interaksi ini juga mempengaruhi individu ketika ia mengalami saat-saat yang tidak menyenangkan atau menekan yang sering sekali terjadi dalam alur kehidupannya. Dalam menghadapi kondisi yang menekan ini, individu sering membutuhkan bantuan dan dukungan dari orang-orang di sekitarnya. Salah satu cara yang dapat membantu seseorang mampu menghadapi kejadian yang menimbulkan stress dan mempertahankan kesehatan yang baik adalah dukungan sosial. Dukungan sosial yang dimaksud dalam hal ini adalah dukungan keluarga sebagai unit sosial yang paling kecil dari masyarakat.

Menurut Baron \& Byrne (2000) dukungan sosial berperan meningkatkan kesehatan tubuh dan menciptakan efek yang positif. Hal senada disampaikan oleh Greenberg (2002) yang mengatakan bahwa keberadaan keluarga dan teman dapat diajak berdiskusi serta memberikan perubahan yang besar bagi individu dalam menghadapi tekanan atau rasa sakit yang dideritanya.

Siegel (dalam Taylor, 1999) menggambarkan dukungan sosial sebagai informasi dari orang lain bahwa ia dicintai dan diperhatikan, berharga, dan dihargai, serta merupakan bagian dari jaringan.Pendapat lain mengenai dukungan sosial juga disampaikan oleh Di Matteo (1991), yang mengatakan bahwa dukungan sosial merupakan bantuan dari orangorang lain yang ada disekitar individu. Hal senada juga disampaikan oleh Baron \& Byrne (2000) bahwa dukungan sosial yang disediakan oleh teman-teman dan anggota keluarga menimbulkan kenyamanan fisik dan psikologis. Lebih lanjut dikatakan Di Matteo (1991:330) dukungan sosial adalah "social support is support or help from other human beings such us friends, family, neighbours, co-workers and acquaintances"

Dari definisi-definisi diatas dapat disimpulkan bahwa dukungan sosial adalah suatu bentuk bantuan dari orang-orang disekitar individu yang dianggap dekat secara emosional, dan berfungsi memberikan kenyamanan fisik dan psikis.

Individu yang menghadapi situasi stres membutuhkan suatu bentuk dukungan sosial dari orang-orang disekitarnya. Bentuk dukungan sosial dan dari siapa ia membutuhkan dukungan tersebut, juga berbeda-beda dari satu individu dengan individu yang lainnya. Ada 5 bentuk dasar dari dukungan sosial yang dapat diberikan 
dan diterima oleh individu (Orford, 1992;:Sarafino,2002), yaitu:

a. Dukungan Emosional: meliputi ekspresi dari rasa empati, perawatan, perhatian. Ini menyebabkan individu merasa nyaman, tenteram, dimiliki, dan dicintai pada saat kondisi yang menekan (Sheridan, 1992). Tolsdorf (dalam Orford, 1992) merujuk kepada bantuan dalam bentuk pemberian semangat, kehangatan pribadi, cinta, atau bantuan emosional.

b. Dukungan Penghargaan: dukungan yang berpengaruh pada peningkatan self esteem dan perasaan kompeten, sehubungan dengan adanya penilaian positif atau persetujuan terhadap ide-ide, perasaan dan penampilan individu, serta adanya perbandingan yang positif antara individu tersebut dengan orang lain.

c. Dukungan Materi: pemberian dukungan yang melibatkan bantuan secara langsung, seperti bantuan finansial ataupun mengerjakan tugas rumah sehari-hari. Dukungan ini relevan dalam menghadapi situasi stress yang dapat dikontrol, dapat membantu meringankan beban dari individu yang memiliki penghasilan rendah, tidak punya cukup keterampilan atau kemampuan untuk melakukan atau mencari pekerjaan formal sehingga mereka dapat memenuhi tanggung jawab atas perannya sehari-hari.

d. Dukungan Informasi: dukungan diberikan dalam bentuk saran, pengarahan, dan umpanbalik mengenai cara menghadapi atau memecahkan masalah yang ada

e. Dukungan Jaringan Sosial: dukungan diberikan dalam bentuk kebersamaan sehingga individu merasa sebagai bagian dari jaringan kelompok yang ada di masyarakat.

\subsection{Pengaruh Dukungan Sosial Terhadap} Kesehatan

Stres yang tinggi dan berlangsung dalam jangka waktu yang panjang atau lama dapat memperburuk kondisi kesehatan dan menyebabkan penyakit. Tetapi dengan adanya dukungan sosial yang diterima oleh individu yang sedang mengalami atau menghadapi stres maka hal ini akan mempertahankan daya tahan tubuh dan meningkatkan kesehatan individu (Baron \& Byrne, 2000). Kondisi ini dijelaskan oleh Sarafino (2000) bahwa berinteraksi dengan orang lain dapat memodifikasi atau mengubah persepsi individu mengenai kejadian tersebut, dan ini akan mengurangi potensi munculnya stress yang baru atau stress yang berkepanjangan.

Taylor (1999) mengatakan bahwa dukungan sosial yang diberikan kepada penderita penyakit dapat mengurangi distress psikologis secara efektif serta menurunkan tingkat kecemasan mereka. Dukungan sosial berperan untuk mencegah terjadinya gangguan medis yang lebih parah atau komplikasi akibat menurunnya fungsi tubuh secara keseluruhan. Hal ini juga sejalan dengan pernyataan Ganster \& Victor (dalam Sheridan \& Radmacher, 1992) bahwa dukungan sosial berpengaruh pada kesehatan dengan mengurangi dampak psikologis negatif dari stress yang muncul karena adanya/ketersediaan dukungan sosial yang mempengaruhi penilaian terhadap stresor dan sumber daya yang ia miliki untuk menghadapi kondisi stress yang muncul.

\section{Metodologi Penelitian}

\subsection{Jenis Penelitian}

Penelitian ini adalah penelitian kualitatif yang bersifat deskriptif dengan studi kasus dimana penulis ingin menggambarkan dukungan keluarga terhadap kelangsungan hidup ODHA. Penelitian deskriptif menurut T.H. Huxley adalah "penelitian yang berusaha mengambarkan secara sistematis fakta-fakta dan karakteristik populasi yang telah ditentukan atau bidang yang diteliti secara faktual dan akurat (Singarimbun, 1982: 8). Penelitian deskriptif lebih lanjut dikatakan oleh Nazir (1985: 63) adalah suatu metode yang meneliti sekelompok manusia, suatu obyek, suatu set kondisi, suatu sistem pemikiran ataupun suatu kelas peristiwa sekarang.

\subsection{Pendekatan Penelitian}

Penelitian ini menggunakan pendekatan kualitatif. Suparlan (1994:25-26) menyebutkan bahwa pendekatan kualitatif memusatkan perhatian pada prinsip-prinsip umum yang mendasari perwujudan satuan-satuan gejala yang ada dalam kehidupan sosial manusia.

\subsection{Unit Analisa}

Merujuk pada masalah dan fokus penelitian, maka yang menjadi unit analisa dalam penelitian ini adalah: 6 orang ODHA, 6 keluarga, 1 orang dokter, 1 orang ahli, 1 orang manajer kasus, 1 orang penjangkau lapangan, 1 lembaga pelayanan AIDS. 


\subsection{Teknik Pengumpulan Data}

Data yang digunakan dalam penelitian ini diperoleh melalui:

a. Kuesioner. Teknik kuesioner adalah suatu teknik pengumpulan data melalui daftar pertanyaan yang diisi responden.Peneliti mendesain dan memberikan daftar pertanyaan yang diisi para informan.

b. Wawancara Mendalam (in-depth interview). Yang dimaksud dengan wawancara mendalam adalah proses memperoleh data dengan tanyajawab tatap muka antara peneliti dengan informan (Sudjarwo, 2001: 75). Pengumpulan data dilakukan dengan menggunakan teknik wawancara yang dilakukan atas dasar kuisioner yang telah dirumuskan sebelumnya. Wawancara ini berguna untuk mencegah ketidakpahaman informan dalam menjawab pertanyaan yang dimaksud kemudian dicatat. Dalam proses wawancara ini peneliti memperoleh gambaran yang lengkap tentang penelitian.

c. Observasi. Observasi dalam penelitian ini dilakukan terutama untuk mengamati hal-hal yang tidak terlihat oleh penelitian karena ekspresi yang diperlihatkan oleh informan kadang kala tidak sesuai dengan apa yang diucapkannya. Hal-hal yang diobservasi adalah yang berkaitan dengan penelitian.

d. Studi kepustakaan. Studi kepustakaan merupakan salah satu sumber informasi yang dilakukan pada awal penelitian ini hingga selesai. Studi kepustakaan memberikan gambaran yang jelas, yaitu dengan mempelajari buku, majalah, internet, surat kabar dan jurnal, yang berkaitan dengan penelitian ini.

\subsection{Penentuan Informan Penelitian}

Penentuan informan ditetapkan secara purposive dengan maksud untuk memperoleh data dan informasi secara akurat. Penentuan informan dalam penelitian ini didasarkan atas kondisi dan situasi ODHA maupun OHIDA, dan peneliti mengambil 6 kasus untuk ODHA dan OHIDA dari 20 informan yang ada. Masing-masing mewakili kelompok IDU, PMCT, Ibu Rumah Tangga, Janda. Penentuan kasus ini dilakukan setelah mempelajari dan mengamati secara intensif kondisi bio-psiko-sosial-spiritual serta interaksi-interaksi dengan lingkungan sosialnya.

\subsection{Teknik Analisa Data}

Teknik analisa data yang diterapkan dalam penelitian ini adalah analisis data kualitatif yang dideskripsikan dalam bentuk uraian. Analisis data kualitatif menurut Bogdan \& Biklen dalam Lexi J. Maleong (2004:248) adalah upaya yang dilakukan dengan cara bekerja dengan data, mengorganisir data, memilah-milahnya menjadi satuan yang dapat dikelola, mencari dan menemukan pola, menemukan apa yang penting dan apa yang dipelajari, serta memutuskan apa yang dapat diceritakan kepada orang lain. Dengan kata lain analisis data adalah proses mencari dan mengatur secara sistimatis transkrip interview, catatan lapangan, dan bahan-bahan lain yang diperoleh dalam penelitian dan proses selanjutnya adalah penarikan kesimpulan. Dalam konteks penelitian ini, analisis data kualitatif adalah analisis yang dilakukan terhadap data-data hasil wawancara atau catatan laporan, bacaan dari buku-buku, artikel, jurnal maupun koran-koran.

\section{Hasil dan Pembahasan}

\subsection{Pengetahuan dan Pemahaman ODHA (Orang Dengan HIV/AIDS)}

Tingkat pemahaman seseorang mengenai suatu hal sangat ditenntukan oleh pengetahuan yang diperolehnya serta kemampuan kognitifnya. Pengetahuan tersebut diterima melalui berbagai sumber seperti pendidikan, pelatihan, lingkungan keluarga, masyarakat dan lembaga-lembaga pelayanan sosial.

Dalam penelitian ini ditemukan bahwa pada umumnya pengetahuan ODHA tentang HIV/AIDS khususnya tentang cara penularan, gejala-gejala serta resikonya, dan pengobatan masih sangat terbatas. Demikian juga mengenai permasalahan yang dihadapi ketika melakukan interaksi dengan lingkungan sosialnya. Ketidaktahuan tentang penyakit serta isu-isu yang terkait disebabkan karena kekurangan dan kesalahan dalam menerimma informasi yang selama ini diperoleh, sehingga berakibat pada cara penerimaan ODHA terhadap penyakit tersebut. Namun demikian ada yang pernah dengar tetapi tidak mengetahui secara mendalam tentang penyakit tersebut. Ada juga yang sudah mengetahui dan memahami tentang penyakit tersebut, kemudian berusaha untuk mencari informasi sebanyak mungkin terkait dengan kondisi yang mereka alami. Berbagai ungkapan yang disampaikan ODHA menunjukan ketidaktahuan dan ketidakpahaman mereka tentang HIV/AIDS dan gejala-gejalanya dianggap sebagai penyakit biasa dan akan sembuh bila minum obat. Mereka tidak menyadari apa yang dialami sebenarnya merupakan gejala awal orang yang terinfeksi HIV/AIDS. 
Pengetahuan yang terbatas mendorong mereka untuk melakukan upaya-upaya untuk memperoleh informasi sebanyak-banyaknya untuk memahami tindakan yyang harus dilakukan dalam menagani penyakit yang mereka derita. Upaya ini dilakukan oleh ODHA karena mereka menyadari bahwa kesakitan yang dialami merupakan ancaman terbesar bagi eksistensi mereka untuk melanjutkan kehidupannya. Penilaian akan ancaman resiko yang menyerang kesehatan serta pertimbangan mengenai keuntungan maupun kerugian yang dialami akibat penyakit HIV/AIDS, mendorong mereka melakukan upaya pencegahan,serta membentuk keyakinan untuk berfikit secara rasional dan realistis tentang kehidupan yang akan dihadapinya apabila tidak segera mengubah perilaku dan pola hidupnya.

Pemahaman tentang penyakit, gejala serta implikasi pengobatan dari penyakit HIV/AIDSakan sangat membantu ODHA mengantisipasi pola hidup hidup yang harus dijalani agar kondisi tubuh tetap stabil.Dalam melewati kehidupan, terkadang sesorang tidak dapat memahami apayang telah terkadi dan menimpa dirinya. Kepedihan dan keraguan terhadap suatu kondisi telah melahirkan keputusasaan tentang masa depannya.Penyakit yang dideritanya telah melenyapkan kesempatan untuk meraih apa yang diinginkan dan diharapkan dalam kehidupan ini.

\subsection{Pengetahuan dan Pemahaman Keluarga}

Setiap sikap dan tindakan seseorang seringkali dilakukan berdasarkan informasiyang diperoleh, kemudian diolah dan ditafsir oleh kemampuan kognitif dalam bentuk pengetahuan dan pemahaman tingkat pemahaman diperoleh dari pengetahuan berdasarkan informasi yang benar, yang selanjutnya memengaruhi perlakuan diberikan terhadap orang lain. Kurangnya informasi dan terbatasnya pengetahuan tentang penyakit HIV/AIDS, menyebabkan keluarga memperlakukan ODHA secara diskriminatif bahkan tidak manusiawi. Perlakuan ini berdampak terhadap relasi dan interaksi antara anggota-anggota keluarga lainnya. Keterkejutan dan kecemasan terhadap penyakit yang dialami oleh anggota keluarga yang terinfeksi HIV/AIDS. Dari keluarga yang diteliti, terlihat bahwa tidak semua keluarga memiliki pengetahuan dan bahkan belum pernah mendengar tentang penyakit tersebut.

Ketidaktahuan serta keterbatasan keluarga dalam mendapatkan informasi tentang HIV/AIDS sangat berdampak terhadap perlakukan anggota keluarga yang terinfeksi HIV/AIDS dan cenderung menolak keberadaan serta memberikan stigma kepada ODHA.Stigma dan perlakuan diskriminatif yang dikaitkan dengan HIV/AIDS merupakan penghambat utama bagi keluarga untuk melakukan upaya pencegahan lanjut dan pelayanan yang dibutuhkan. Demikian juga bagi dukungan dan perawatan serta pengurangan dampak buruk infeksi HIV AIDS. Artinya jika keluarga sebagai lingkungan terdekat ODHA tidak mengetahui maupun memahami mengenai penyakit yang dialami oleh anak atau anggota keluarganya, maka berpengaruh pada dukungan yang seharusnya diberikan pada ODHA. Sebaliknya pengetahuan dan pemahaman yang jelas dimiliki keluarga membantu interaksi antara ODHA dengan lingkungan sosialnya. Dengan demikian dukunngan keluarga akan meningkat apabila memiliki pengetahuan dan pemahaman tentang HIV/AIDS. Dan inilah yyang sangat dibutuhkan ODHA dalam proses penyembuhan secara menyeluruh baik itu kesehatan fisik, mental, spiritual maupun sosial.

\subsection{Pengetahuan dan Pemahaman Dokter,} Manajer Kasus, dan Petugas Lapangan

Dokter dan perawat merupakan ujung tombak dalam pelayanan medis untuk membantu individu sembuh dari penyakitnya. Penyembuhan itu sendiri merupakan proses untuk mengubah dari keadaan sakit menjadi sehat. Di sini kalangan medis memiliki peranan yang besar dalam proses penyembuhan seorang pasien. Sekalipun infeksi HIV dan Penyakit AIDS merupakan penyakit yang mematikan, ternyata dari kalangan medispun, sebagai sumber informasi yang harusnya memberikan penjelasan yang baik bagi ODHA dan keluarganya juga sangat terbatas. Hal ini mengindikasikan bahwa kalangan medis sebagai garda terdepan dalam menyampaikan berbagai informasi tentang HIV yang benar bagi ODHA maupun keluarga, sebaliknya justru menciptakan suatu kondisi yang tidak nyaman dan kondusif bagi ODHA dalam menjalani perawatan di rumah sakit.

Perlakuan diskriminatif yang diberikan oleh pihak rumah sakit, jelas mengakibatkan tekanan dan menghambat proses pennyebuhan ODHA, serta memengaruhi keadaan psikologis keluarga yang merupakan pendukung utama bagi ODHA dalam menjalankan kehidupannya yang penuh dengan prasyarat untuk kelangsungan hiduoonya yang disebabkan oleh penyakitnya. Penelitian ini 
memperlihatkan bahwa kekurangan dan ketidakjelasan informasi tentang HIV/AIDS dari pihak rumah sakit malah menambah kebingungan dan keresahan keluarga. Keterbatasan pengetahuan dan pemahaman dokter maupun perawat tentang HIV/AIDS antara lain ditentukan oleh kebijakannyang ada di pusat pelayanan kesehatan. Apabila pimpinan paham tentang HIV/AIDS dan pentingnya memberikan pelayanan yang sesuai, maka tenaga medisnya akan dibekali dengan berbagai program yang berhubungan dengan isu-isu HIV/AIDS. Masalah seringkali terjadi apabila pimpinan diganti oleh orang baru yang belum paham. Situasi ini menyebabkan keluarga tidak mau melakukan pemeriksaan kesehatan. Jika hal ini dibiarkan, maka para ODHA akan kesulitan memperoleh pengobatan, dan lebih jauh lagi akan mempengaruhi upaya pemerintah yang sedang menggalakkan penanggulangan HIV/AIDS.

Disamping dokter dan perawat yang secara langsung memberikan pelayanan, Manajer Kasus dan Petugas Lapangan merupakan pihak yang juga berinteraksi bahkan melakukan pendampingan sejak ODHA berada dalam situasi terpuruk hingga sehat. Tugas utama manajer kasus adalah melakukan koordinasi dengan berbagai sumber untuk mengakses layanan yang dibutuhkan dan harus diberikan kepada ODHA serta keluarganya. Selain melakukan koordinasi, seorang manajer kasus harus mengikuti pelatihan untuk mengetahui secara benar tentang apa saja yang terkait dengan penularan HIV sejak saat seseorang mulai tertular hingga menggunakan terapi ARV.Dalam menjalankan tugas dan fungsinya, manajer kasus dibantu oleh petugas lapangan.

Perugas lapangan adalah orang yang melakukan penjangkauan terhadap kelompokkelempok yang beresiko tertular atau yang terinfeksi HIV namun tidak dapat mengakses layanan di masyarakat karena berbagai factor yang dialami, utamanya keadaan ekonomi, stigma dan diskriminasi. Dalam melakukan penjangkauan, petugas lapangan menyampaikan informasi dasar tentang HIV/AIDS serta isu-isu terkait.

Perlakuan diskriminatif yang diberikan oleh perawat pada ODHA maupun keluarga saat dirawat di rumah sakit disebabkan karena terbatasnya pengetahuan maupun pengalaman yang mereka miliki untuk melayani penderita HIV/AIDS. Pengetahuan dan pemahaman yang dimiliki oleh manajer kasus maupun petugas lapangan tentang HIV/AIDS merupakan faktor pendukung dalam menjangkau, mengoordinasi, memberikan akses dan memastikan diperolehnya pengobatan dan pelayanan bagi ODHA. Dengan demikian maka pengetahuan dan pemahaman yang kurang sangat mempengaruhi pandangan seseorang terhadap suatu penyakit dan resikonnya. Artinya jika mereka memiliki pengetahuan dan pemahaman yang memadai, amka akan mempengaruhi sikap dan perilaku dalam memberikan pelayanan bagi ODHA maupun keluargannya.

\subsection{Permasalahan yang Dialami ODHA}

Situasi dan perlakuan yang dialami dan diterima oleh ODHA dari lingkungan kerja maupun masyarakat, menimbulkan sikap atau kondisi yang dapat berpengaruh terhadap situasi sosial, psikis maupun kesehatan mereka. Sikap reaktif yang ditunjukan masyarakat terhadap ODHA yang disebabkan karena selama inni telah terbentuk opini yang salah. Masyarakat beranggapan bahwa karena penyakit HIV merupakan penyakit yang berbahaya dan belum ada obatnya, mereka menjadi takut jika di wilayah mereka ada yang terinfeksi HIV. Sikap yang diperlihatkan oleh masyarakat demikian ini menggambarkan betapa kurangnya informasi yang diperoleh sehingga menimbulkan diskriminasi dan stigmanisasi yang berlebihan. Hal ini berakibat terhadap keberlangsungan hidup ODHA, baik secara fisik, psikis, maupun sosial dan spiritual.

Persoalan yang dihadapi ODHA akibat virus yang menyerang tubuhnya, berdampak terhadap proses pemulihan yang dijalankan oleh mereka. Permasalahan yang dihadapai dari aspek medis, psikologis, sosial-ekonomi dan spiritual.

Dari aspek medis, tidak dapat dipungkiri bahwwa jika seseorang terserang penyakit apalagi penyakit yang membahayakan, maka mereka tidak dapat menjalankan aktivitas sebagaimana mestinya karena kondisi tubuh melemah, dan tidak berdaya. Kondisi ini jelas menghambat pekerjaan maupun kegiatan kesehariannya.Disamping itu, perlakuan diskriminatif yang diberikan oleh pihak rumah sakit memperparah penyakit yang dialami oleh ODHA. Hal ini merupakan faktor yang sangat mempengaruhi proses kesembuhan yang sedang dijalaninya. Selain aspek medis, aspek lain yang juga berpengaruh dalam proses kesembuhan yaitu psikologis.

Aspekpsikologis tercermin dalam ketakutan, keccemasan, kesedihan, kebingungan, kemarahan dan kehilangan rasa percaya diri serta 
keputusasaan ketika mengetahui tentang penyakitnya. Kondisi ini jelas mempengaruhi proses perawatan dan pemulihan ODHA. Faktor fisik dan psikologis memiliki hubungan timbal balik yang sangat erat. Keadaan fisik seseorang menentukan kestabilan jiwannya. Selain aspek medis dan psikologis, aspek lain yang dialami oleh ODHA adalah aspek sosial. Perlakuan dari lingkungan tetangga maupun lingkungan kerja yang bersifat diskriminatif yang disertai stigma terhadap ODHA menyebabkan mereka terisolasi dan tidak diberikan kesempatan yang sama untuk meraih masa depan. Perlakuan seperti ini menghambat ODHA dalam berinteraksi dengan lingkungannya serta mempengaruhi seluruh aspek kehidupannya. Kedekatan maupun interelasi yang terjadii dengan orang-orang yang berada disekitar ODHA membantu untuk melihat kehidupan yang lebih berrmakna dan berharga bagi dirinya maupun orang lain. Artinya lingkungan memberikan peluang dan kesempatan bagi ODHA dalam meningkatkan kemampuan dan produktivitas sekalipun dalam keadaan sakit.

Selain ketiga aspek diatas, aspek ekonomi dalam hal ini keuangan juga berperan penting dalam kehidupan ODHA untuk melakukan pemeriksaan, pengobatan dan perawatan rutin, terutama terapi obat ARV. Apabila ODHA tidak mengkonsumsi ARV secara berkesinambungan, maka tubuhnya akam mengalami resistensi yang berakibat pada kematian.

\subsection{Permasalahan yang dihadapi Keluarga}

Permasalahan yang dihadapi keluarga umumnya terkait dengan ketidakmampuan untuk membiayai perawatan dan pengobatan anggota keluarga yang terinfeksi HIV. Karena keluarga tidak memiliki pekerjaan, selain itu juga masalah lain adalah ketegangan, kecemasan dan tidak harmonisnya relasi antara mereka apalagi ketika informasi tentang status ODHA belum atau tidak diketahui oleh seluruh keluarga. Mereka juga mengalami perlakuan yang diskriminatif dari lingkungan masyarakat tempat tinggalnya. Selain permasalah diatas, permasalahan lain yaitu masalah yang ditinjau dari aspek psikologis, sosial, ekonomi dan spiritual.

Aspek psikologis, ketidaktahuan karena kurangnya informasi tentang penyakit HIV, menimbulkan reaksi yang berlebihan dari keluarga seperti ketakutan, kecemasan, kegalauan, serta kesedihan yang ditujukan tanpa didasarkan pada pemahaman yang benar berakibat terhadap dukungan yang diberikan.Disamping aspek psikologis yang dialami, aspek yang sangat mempengaruhi interaksi keluarga dengan linngkungan adalah aspek sosial. Aspek ini berdampak terhadap hubungan keluarga maupun ODHA dengan lingkungan, baik itu lingkungan keluarga besar maupun lingkungan masyarakat.Dengan demikian dalam mengatasi kegoncangan yang dialami keluarga, dibutuhkan nilai-nilai untuk menuntunya dalam mengambil keputusan atau memberikan makna pada kehidupannya.

\subsection{Bentuk-Bentuk Dukungan Yang Diberikan} Keluarga

a. Dukungan Emosional. Dukungan emosional merupakan suatu upaya yang diberikan dalam memperlihatkan perasaan maupun kasih sayang terhadap seseorang ketika berada dalam kondisi labil. Hal ini seperti yang ditunjukan oleh keluarga ketika ada anggota keluarga yang terinfeksi HIV/AIDS

b. Dukungan Penghargaan. Perhatian dan penerimaan keluarga kepada ODHA, merupakan suatu semangat bagi ODHA dalam menjalani kehidupan mereka. Adanya penerimaan dari keluarga berdampak secara signifikan dalam proses pengobatan yang dilakukan oleh ODHA.

c. Dukungan Materi. Berbagai cara dilakukan oleh keluarga untuk membantu pengiobatan anaknya. Mereka melakukan berbagai cara untuk memperoleh uang agar dapat membeli obat yang dikonsumsi oleh anggota keluarga yang terinfeksi.

d. Dukungan Informasi. Upaya yang dilakukan oleh keluarga besar saat menerima atau mengetahui tentang kondisi anggota keluarga yang terinfeksi HIV adalah berusaha untuk mencari informasi sebanyak mungkin terkait dengan penyakit yang dialami oleh anak atau anggota keluarganya, disamping itu mereka meminta saran dari berbagai pihak yang berkepentingan terkait dengan kondisi yang dialami oleh anak/anggota keluarga lainnya.

e. Dukungan Bersosialisasi. Setelah mengumpulkan informasi dan memperoleh saran dari berbagai pihak maka keluarga berusaha untuk terlibat di lembaga-lembaga yang memberikan pelayanan kepada orang dengan HIV/AIDS yaitu melalui kepompokkelompok dukungan. Upaya yang dilakukan keluarga merupakan suatu cara untuk membantu Orang Dengan HIV/AIDS tidak merasa terisolasi dari lingkungan sosialnnya. 
Karena saat lingkungan masyarakat telah membentuk suatu lingkaran yang membatasi kehidupan Orang Dengan HIV/AIDS, maka peran keluarga sangat penting dalam membantu Orang Dengan HIV/AIDS melewati berbagai tekanan eksternal yang diterima. Bantuan atau dukungan dari keluarga sangat berarti untuk ODHA dalam melalui hari-hari dalam kehidupannya. Berbagaibentuk dukungan yang diberikan keluarga dalam mendukung ODHA menjalani dan melewatisaat-saat yang kritis berupa dukungan emosional, penghargaan, materi, informasi dan sosialisasi. Ini penting bagi keluarga, karena dukungan yang berarti dan positif mempercepat penyembuhan dan meningkatkan kepercayaan diri ODHA dalam menatap masa depan. Selain itu juga, situasi yang kondusif dan nyaman bagi ODHA dalam melakukan interaksi dengan lingkungan dan dapat melakukan aktivitas serrta mengikuti berbagai kegiatan.

\section{Kesimpulan dan Saran}

5.1 Kesimpulan

a. Pengetahuan dan pemahaman Orang Dengan HIV/AIDS (ODHA) yang sangat terbatas cukup berpengaruh terhadap kondisi kesehatan mereka. Ketidaktahuan dan ketidakpahaman saat terinfeksi penyakit HIV/AIDS, terefleksi pada anggapan bahwa gejala-gejala seperti pingsan, diare secara terus menerus, luka maupun jamur disekitar mulut adalah penyakit biasa dan akan sembuh bila minum obat. Ketidakjelasan tentang informasi HIV/AIDS yang benar, membuat ODHA tidak terlalu mempedulikan pennyakit yang dialami serta melakukan pencegahan agar tidak terinfeksi virus yang lainnya.

b. Ketidakjelasan akan informasi yang diperoleh berdampak terhadap reaksi yang ditimbulkan saat mengetahui salah satu anggota keluarga yang terinfeksi HIV/AIDS. Keluarga hanya mengetahui bahwa HIV merupakan penyakit yang berbahaya, dapat ditularkan melalui makanan, minuman, maupun air dan juga tempat duduk yang diduduki oleh ODHA. Pengetahuan dan pemahaman yang salah dari keluarga tentang HIV/AIDS berdampak terhadap sikap yang ditunjukkan kepada anak/anggota yang terinfeksi virus mematikan tersebut. Dengan demikian pengetahuan dan pemahaman akan informasi yang jelas dan benar tentang penyakit HIV/AIDS, akan membantu keluarga dalam memberikan dukungan dan pelayanan pada ODHA serta dapat meningkatkan motivasi ODHA dalam menjalani kehidupannya.

c. Keterbatasan pengetahuan dan minimnya pengalaman tenaga medis tentang penyakit HIV/AIDS berdampak terhadap pelayanan yang diberikan kepada ODHA maupun keluarga. Tenaga medis sebagai ujung tombak dalam memberikan bantuan seharusnya memperlakukan ODHA dengan wajar tanpa membedakan memreka dengan pasien lain. Pengetahuan dan pemahaman yang dimiliki oleh manajer kasus maupun petugas lapangan tentang HIV./AIDS merupakan faktor pendukung dalam pemberian layanan mereka. Pengetahuan dan pemahaman yang kurang sangat mempengaruhi pandangan seseorang terhadap suatu penyakit.

d. Permasalahan yang dihadapi oleh ODHA yaitu masalah medis, psikologis, sosial mauppun ekonomi. Aspek medis yang dialami oleh ODHA terkait dengan minimnya informasi yang diperoleh sehingga berdampak terhadap pola prilaku yang ditimbulkan dari ketidaktahuan tentang HIV.Selain aspek medis, kondisi psikologis yang diperlihatkan oleh ODHA saat mengetahui status yaitu sedih, cemas, terisolasi dan kehilangan kepercayaan diri serta putus asa. Kondisi ini sangat mempengaruhi proses pemulihan terkait dengan penyakit HIV/AIDS, selain kedua aspek yang disebutkan diatas, aspek lain yaitu aspek sosial seperti stigma dan diskriminasi yang menghambat ODHA dalam meraih kesempatan untuk maju.

e. Permasalahan yang dihadapi oleh keluarga ditinjua dari aspek psikologis, sosial dan ekonomi. Reaksi yang diperlihatkan keluarga saat pertama kali mengetahui salah satu anggota keluarganya yang terinfeksi HIV/AIDS adalah kaget, sedih, marah dan bingung serta takut, reaksi ini muncul didasarkan pada kurangnya informasi dan pengetahuan akan penyakit, sehingga berdampak pada perlakuan yang diberikan kepada ODHA.

f. Keluarga sebagai lingkaran terdekat bagi ODHA, memiliki pengaruh yang besar terhadap proses perkembangan kesehatan ODHA. Dukungan yang diberikan memiliki arti dan tujuan yang positif untuk pemulihan kondisi ODHA, serta merupakan suatu sikap yang dapat membantu ODHA melewati masamasa sulit terkait dengan penyakitnya. Dukungan yang positif ini dapat meningkatkan kepercayaan diri dalam memaknai setiap 
peristiwa yang dialami dan dapat melakukan sesuatu yang berguna bagi dirinya maupun orang lain.

g. Bentuk-bentuk dukungan yang diberikan oleh keluarga, berpengaruh secara signifikan terhadap keberlanngsungan hidup ODHA. Dukungan-dukungan yang diberikan oleh keluarga berupa dukungan emosional, dukungan materi, dukungan penghargaan, dukunngan informasi, dan dukungan jaringan sosial. Dengan demikian maka dapat disimpulkan bahwa keluarga merupakan tempat utama ODHA maupun anggota keluarga yang lainnya dalam melewati masa-masa kritis, dan keluarga juga memberikan dorongan bagi individu untuk dapat melihat hidup lebih berarti dan berguna bagi dirinya maupun orang lain.

\subsection{Saran}

\section{a. Saran Bagi Keluarga}

1. Memperlakukan anak maupun anggota keluarga yang terinfeksi HIV sebagai manusia yang bermartabat, karena penerimaan dan perlakuan yang positif dari keluarga akan sangat membantu mengatasi tekanan eksternal maupun internal;

2. Memberikan dukungan terhadap kehidupan ODHA untuk menjalani kehidupan secara positif dan bermakna;

3. Menggali informasi sebanyak mungkin tetang apa yang dialami oleh anggota yang terinfeksi HIV, untuk menghindari perlakuan diskriminatif.

b. Saran Bagi Lembaga Pelayanan Sosial (AIDS)

1. Lembaga pelayanan AIDS sebagai garda terdepan dalam memberikan bantuan kepada masyarakat terutama ODHA, agar memperlakukan mereka tanpa membedakannya dengan yang lain;

2. Mengadakan pertemuan rutin maupun kegiatan yang mendukung kehidupan sosial bagi keluarga maupun ODHA;

3. Meningkatkan koordinasi dan kerjasama dengan masyarakat maupun tokoh agama dalam menyebarluaskan informasi tentang HIV/AIDS;

4. Melakukan sosialisasi tentang programprogram lembaga kepada lingkungan agar lingkungan sadar dan tidak memberikan stigma serta diskriminasi terhadap masyarakat yang terinnfeksi HIV/AIDS.

c. Saran Bagi Lembaga Pendidikan Pekerjaan Sosial
1. Memasukan dalam kurikulum Pendidikan Pekerjaan Sosial mengenai HIV/AIDS, karena masalah ini semakin meningkat dan membutuhkan intervensi pekerjaan sosial yang profesional;

2. Meningkatkan kerjasama dengan lembagalembaga yang menangani HIV/AIDS untuk merencanakan penyusunan kebijakankebijakan terkait.

\section{REFERENSI}

Barker, L. Roberth (ed). 1998.The Social Work Dictionary $4^{\text {th }}$. NASW Press

Baron, RA and Byrne.1991.Social Psycology : Understanding Human Interaction $6^{\text {th }}$. USA: Allyn \& Bacon.

Burhan Bungin. 2001.Metode Penelitian Sosial Format-format Kwantitatif dan Kualitatif. Airlangga University Press

Dimatteo, M. Robin. 1991.The Psycology of Health, Illness and Medical Care: An Individual Perspective. California: Brook/Cole Publishing Company

Djoerban, Zubairy. 1999.Membidik AIDS: Ikhtiar Memahami HIV dan ODHA.Yogyakarta : Galang Press

GAA, Muninjaya. 1998.AIDS di Indonesia: Masalah dan Kebijakan Penanggulangannya. Buku Kedokteran EGP.

Gerungan, WA. 2000.Psikologi Sosial.Bandung: PT Refika Aditama.

Gottlieb, BH1983.Social SuportStrategies: Guidelines for Mental Health Practice. California: Sage Publications, Inc. 
H.D. Bastaman. 1993.Pola Keberhasilan Mengembangkan Penghayatan Hidup Bermakna. Jakarta : UI Press.

H.S. Sudjarwo. 2001.Metodologi Penelitian Sosial. Bandung: Mandar Maju

Moleong, Lexy J. 2004. Metode Penelitian Kualitatif.Bandung: Remaja Rosdakarya.

Muma, D. Richard, et all.1997.HIV Manual untuk Tenaga Kesehatan.Jakarta: EGC

Mulyadi, Yadi. 1995.Sosiologi Keluarga. Jakarta: PT Gramedia.

Robert, R. Balker., Greene, J. Gilbert. 2008.Buku Pintar Pekerja Sosial.Jakarta: BPK Gunung Mulia.

Yuen, K.O., et. all. 2003.Family Health Social Work Practice: A Kowledge and Skill Casebook. The Haworth Press, Inc.

1996.Meraih Hidup Bermakna. Jakarta: Paramadina

Lain-Lain:

Families In Society- The Journal of Contemporary Human Service. July-August, 2002, Volume 83 Number 4.Engulfing Darkness: The Impact of HIV/AIDS on the Family by Premillia D'Cruz. Families International, Inc.

*Nancy Rahakbauw, Dosen S1 Ilmu Kesejahteraan Sosial FISIP Universitas Kristen Indonesia Maluku (UKIM) Ambon

Email: nancyrahakbauw@yahoo.com 